\title{
Problems and Countermeasures of College Students' Ideological and Political Education
}

\author{
Zhong-fang Chen \\ Guangdong University of Science \& Technology, Dongguan, China
}

Keywords: colleges and universities; college students; ideological and political education; problems; countermeasures

\begin{abstract}
For the current ideological and political education in colleges and universities, we are generally emphasis on the leading role of teachers too much. To a certain extent, the current ideological education of college students neglects the dominant position of students. Many college students passively accept the educational content of the educators, so the effectiveness of ideological and political education in colleges and universities in our country needs to be strengthened. We educators should actively improve the ideological and moral qualities of college students and realize the great rejuvenation of the Chinese nation while building a harmonious society. In this paper, after analyzing the existing problems of ideological and political education of college students in our country, we put forward the corresponding countermeasures for the ideological and political education of college students according to these problems. In addition to studying the existing problems in the ideological and political education of college students, we can give some advice to the ideological and political education of college students in our country.
\end{abstract}

\section{Introduction}

The ideological and political education of college students have always been a very important part of colleges and universities. The ideological and political education of college students are related to the development of students, schools and the society. The development of a country needs talent, and colleges and universities are the cradle of cultivating talents. Colleges and universities have always regarded the social cultivation of more social talents as their goal and carried out various teaching work. Ideological and political work are even more important among them.

Since the end of 1949, when the National Education Conference was held and the organization of the ideological and political education for college students was organized, the work of ideological and political education in colleges and universities in our country have gone through 63 years. The sixty-three years of exploration and development have provided rich reference materials for clarifying the characteristics, problems and corresponding countermeasures of ideological and political work of college students in our country at the present stage.

With the deepening of reform and opening up and the full popularization of the Internet, the diversification of social culture has become increasingly clear. Some Western countries.However, many college students are not self-control.Some adverse social phenomena and temptations, ideas and attitudes have been underestimated the negative impact. Such as college students compete with each other, smoking and alcohol and fall into the phenomenon of gambling. The gradual erosion of college students' thinking has led to a lack of firm political stance and chaos in values. Therefore, under the influence of the factors of this era, all major colleges and universities have been greatly hindered in carrying out their ideological and political work among students.

\section{Problems in College Students' Ideological and Political Education}

The beginning of Chinese universities is derived from the predecessor of Tianjin University and the end of the government supervision of the Northern University. Beiyang University was a government-type school which the reformists used to cultivate talents and save the nation in the late Qing Dynasty. Therefore, the college students were protected by the court and restricted by the 
imperial court at that time. At that time, the undergraduates were in the enlightenment stage and they actively sought for progress in their thinking.By the 1920s and 1930s, undergraduates had grown into powerful forces influencing social development and even directly influenced the direction of the country's progress. But today, with the popularization of education, college students are no longer to the previous college students. They have some common problems in ideological and political education.

\subsection{The profound impact of traditional teaching habits}

On the one hand, the contents of ideological and political courses in colleges and universities generally are too large and the center of gravity is not clear enough. On the other hand, there are problems with obsolete content.There is a single rigid case in teaching methods. The kind of teaching mode has great problems in the political standpoint. As a college ideological and political teacher, this erroneous political inclination should never appear.

2.2 The theory of college students' ideological and political education is not systematic enough

Many theoretical studies in our country draw on the existing western research results and the theory of ideological.The political education acceptance is no exception. The actual situation in China is quite different from that in the West. China needs its own theories, roads and spirits. In addition, the current research on the theory of ideological and political acceptance in our country is still relatively shallow and the perspective is still relatively simple. Even some experts in theoretical research simply confuse the theory of ideological and political education with the theory of the acceptance of ideological and political education. The effect is simple attributed to the problem of the instructor. Theoretical innovation is the forerunner of innovation in all aspects. Ideological and political education lacking theoretical innovation have always been difficult to achieve breakthrough development.

\subsection{Teachers and students do not have enough understanding of ideological and political education}

Some college students think college ideological and political education are not important.The lack of enthusiasm for the main body of learning is an important reason for the low efficiency of ideological and political education in colleges and universities. Ideological and political education in colleges and universities ineffective are duty-bound teachers. The prejudice to the ideological and political work in colleges and universities are the important reasons that affect their professional standards. In addition, in the ideological understanding, some college ideological and political education practitioners also exist in the ideological.Political education is equal to the professional education or the same errors in political education.

\subsection{Students can not understand and absorb the relevant theories of ideology and politics}

Integration of internalization and externalization practice are independent and closely linked to two important links.The receiving subject is a conscious and independent individual, and it will inevitably respond to the external message delivered by the preacher.Of course, the ideological and political education in colleges and universities teachers teaching philosophy will also affect the internalization and externalization of the relationship.Light practice is to make the internalization and externalization appear out of step human factors.

\subsection{There is no uniform standard of education for college students' ideological and political education in our country}

Moral examinations need to consider more about the degree of internalization and the depth of externalized practice, which is difficult to detect by the score of this form. The test applies only to qualitative and quantitative analysis, but for moral assessment, it is difficult to measure from these two aspects. Therefore, the lack of a scientific and systematic evaluation theory and operation mechanism are the final link that affects the acceptance of ideological.

\section{Countermeasures for College Students' Ideological and Political Education}

Ideological and political education for college students are some effective ways to train students. In recent years, based on the experience gained, this work has continuously explored and achieved remarkable results. The majority of students' ideological and political qualities have been markedly 
improved, and the mainstream of their thinking has shown a positive trend of stability, health and upward mobility. Although there is a good situation, this article sums up some measures of ideological and political education for college students according to the actual situation. All these measures are summarized according to the previous problems and are also summarized in Table 1 below.

Problems and Countermeasures of College Students' Ideological and Political Education

\begin{tabular}{|c|c|c|c|c|c|}
\hline Question & $\begin{array}{l}\text { The profound } \\
\text { influence of } \\
\text { traditional } \\
\text { teaching habits }\end{array}$ & $\begin{array}{l}\text { The theory is not } \\
\text { systematic enough }\end{array}$ & $\begin{array}{l}\text { Understanding } \\
\text { is not deep } \\
\text { enough }\end{array}$ & $\begin{array}{l}\text { Theory can not } \\
\text { understand and } \\
\text { absorb }\end{array}$ & $\begin{array}{l}\text { There is no } \\
\text { uniform } \\
\text { measure }\end{array}$ \\
\hline $\begin{array}{l}\text { Counter } \\
\text { measures }\end{array}$ & $\begin{array}{l}\text { According to the } \\
\text { physiological } \\
\text { needs of students } \\
\text { to pay attention } \\
\text { to the ideological } \\
\text { reform }\end{array}$ & $\begin{array}{l}\text { create a reasonable } \\
\text { ideological and } \\
\text { political } \\
\text { environment }\end{array}$ & $\begin{array}{l}\text { Clarify the } \\
\text { relationship } \\
\text { between the } \\
\text { educator and } \\
\text { the } \\
\text { undergraduates }\end{array}$ & $\begin{array}{l}\text { Realization of } \\
\text { internalization } \\
\text { and } \\
\text { externalization } \\
\text { simultaneously }\end{array}$ & $\begin{array}{l}\text { Carry out } \\
\text { ideological } \\
\text { education } \\
\text { reform in } \\
\text { college class }\end{array}$ \\
\hline
\end{tabular}

\subsection{According to the physiological needs of students to pay attention to the ideological reform}

Maslow's theory of demand is widely used. Anyone who is satisfied with material needs will move toward higher demand. Maslow's demand theory can also be fully utilized in ideological and political education in colleges and universities. For the reasonable needs of students, college teachers create conditions to meet as much as possible. After students' needs are met, they will be motivated to pursue their higher needs. On the other hand, we should guide students to establish reasonable needs, abandon the need of selfishness and selfishness and abandon the tendency of emphasizing materialism and lightness.Through various forms of psychological counseling and setback education,colleges and universities reduce the students who can not be met.

\subsection{The community should create a reasonable ideological and political environment for} college students together

We should fully optimize the socio-economic, political and cultural environment and optimize the family environment and campus environment. On any one hand, there is not enough environment to create the environment, which will have an impact on the effectiveness of ideological and political education in colleges and universities. Therefore, in our society, we must create a reasonable ideological and political environment for college students and make a contribution to the improvement of their thinking.

\subsection{Clear education and college students master-slave relationship}

To be effective, we must give full play to the leading role of teachers and the main role of students, which is an effective way to enhance the effectiveness of education. To this end, on the one hand, colleges and universities must create a good atmosphere and provide all the necessary conditions to ensure the smooth progress of all aspects of teaching. When discovering that there are some deviations in the minds of recipients.It is necessary to promptly guide them to accept the main body. On the other hand, colleges and universities should guide the accepting subjects to establish correct values, train their thinking and establish a scientific way of thinking through various effective ways. 


\subsection{Achieve internalization and externalization parallel at the same time}

To make college students clear the content of practice,which is to do a good job of internalization. All education ultimately needs to be settled in practice, and practice is the purpose and destination of life. In ideological education, college students should be guided to love the party, patriotism and spirit. They must cultivate good moral character of the subject. At the same time, they should carry out drastic reforms in curriculum theory and regard externalization as an important educational content. In the practice of form, we should conduct all-round.

\subsection{Implement Ideological Education Reform in College Class}

Teaching methods must be diversified, we can use the system of teaching, thematic teaching, case teaching a combination of ways. Each full-time political teacher in the university should regard the classroom as the main battlefield. Through small-class teaching and inspiration-induced teaching in the classroom, the teaching is more and more stereoscopic and visualized through the combination of modern teaching methods. In the assessment methods, it vigorously carry out the reform. In addition to adherence to the original test evaluation of this way, you can also increase the oral examination, social practice and other forms of comprehensive assessment.

\section{Conclusion}

All in all, there is an objective predicament in the process of ideological and political education in colleges and universities. However, we believe that the effectiveness of ideological and political education can be greatly enhanced in higher education if effective measures are taken.The entire society cooperates fully and the recipient's main role are played.

\section{References}

[1] Chen Changxing. "Ideological and Political Theory Course Students' Subjectivity Perspective", "Heilongjiang Higher Education Research", 2008No.12

[2] Zhong Wenyuan, Lu Wenzhong. "University of ideological and political theory teaching effectiveness - based on the ideological and political education space theory perspective", "Higher Education Journal", No. 1, 2016

[3] Guo Yujing. "Alienation and Reversion of the Main Body of Ideological and Political Education in Colleges and Universities - From the Perspective of Marx's Alienated Labor Theory", "Education and Teaching Research", No.8, 2010

[4] Changchun Hung. "An Overview of Mao Zedong Thought and the Theoretical System of Socialism with Chinese Characteristics" lesson "Panorama" Teaching Exploration [J]. Ideological and Political Education Research, 2012 (4) 